\title{
Pengaruh Self-Enhancement dan Authenticity terhadap Prediksi Diri Masa Depan
}

\section{The Effect of Self-Enhancement and Authenticity to Predict Future}

\author{
Amalia Adhandayani ${ }^{1}$, Bagus Takwin ${ }^{2}$ \\ Fakultas Psikologi, Universitas Indonesia \\ $\underline{\text { amalia.adhandayani@ui.ac.id, bagustakwin@gmail.com }}$
}

\begin{abstract}
KATA KUNCI : Self-Enhancement, Authenticity, Prediksi Masa Depan, Jarak Psikologis
KEYWORDS : Self-Enhancement, Authenticity, Future Predictions, Psychological Distance
\end{abstract}

ABSTRAK: Prediksi masa depan sangat penting bagi kebermaknaan hidup manusia. Penelitian ini bertujuan untuk melihat pengaruh self-enhancement dan pengalaman otentik atau tidak otentik yang dimiliki individu terhadap prediksi masa depan hidup mereka. Selain itu, diharapkan penelitian ini mampu memperkaya literatur tentang self-enhancement atau peningkatan diri yang masih sedikit diteliti di Indonesia. Penelitian ini menggunakan metode eksperimen dengan desain acak 2 (self-enhancement: tinggi vs rendah) x 2 (authenticity: otentik vs tidak otentik) dan between subjects. 120 partisipan dilibatkan dalam penelitian ini. Teknik analisis ANOVA faktorial digunakan untuk melihat perbedaan antar kelompok yang diuji. Hasil penelitian menunjukkan bahwa orang dengan self-enhancement tinggi memiliki hasil yang lebih baik dalam prediksi masa depan dibandingkan orang dengan selfenhancement rendah. Dengan jarak psikologis yang jauh, individu akan lebih cenderung memiliki prediksi masa depan yang lebih positif, sehingga tinggi atau rendah tingkat self-enhancement seseorang tidak berdampak pada skenario masa depan yang mereka buat. Terlepas dari pengalaman otentik atau tidak otentik, hasil penelitian ini menunjukkan bahwa sebagian besar partisipan mengemukakan gambaran masa depan mereka secara optimis. Lebih lanjut, diharapkan penelitian selanjutnya mampu meningkatkan jumlah partisipan sehingga hasil eksperimen dapat dianalisis dengan lebih optimal.

ABSTRACT Future predictions are meaningful for human life. This study aims to examine the effect of self-enhancement on the individual and authentic or unauthentic experiences that individuals have for predicting the future of their lives. In addition, this study is expected to enrich the literature on self-enhancement in Indonesia. This research using experimental method with design of random assignment 2 (self-enhancement: high vs low) $x 2$ (authenticity: authentic vs. not authentic) and between subjects. 120 participants were included in this study. ANOVA factorial analysis technique was used to see the differences in between tested groups. The results show that people with high selfenhancement have better results in future predictions than people with low self-enhancement. With a distant psychological distance, individuals will be more likely to have more positive predictions of the future, so the high or low level of one's self-enhancement does not impact the future scenario they make. Regardless of authentic or inauthentic experience, the results of this study show that most participants present their future picture optimistically. 
Furthermore, it is expected in subsequent research to increase the number of participants so that the experimental results can be analyzed more optimally.

\section{PENDAHULUAN}

\section{Latar Belakang}

Prediksi masa depan sangat penting bagi kebermaknaan hidup manusia. Kita perlu untuk memprediksi cuaca di esok hari, kondisi makanan yang kita simpan dalam seminggu, atau reaksi dari pasangan ketika kita memutuskan hubungan sepihak (Liberman, Trope \& Rim, 2011). Tanpa prediksi, kita juga tidak akan bisa memperkirakan apakah kita mampu meraih gelar sarjana tepat waktu, apakah kita mampu menikah di usia muda, atau apakah kita mampu mencapai tujuan-tujuan kita dalam hidup. Liberman, Trope \& Rim (2011) menyatakan bahwa untuk memprediksi masa depan, individu menggunakan pengalaman yang saat ini mereka rasakan dan pengalaman mereka di masa lalu. Selanjutnya, prediksi masa depan dibuat dengan membangun jembatan antara masa lalu yang telah dilalui dan masa depan yang tidak pernah mereka ketahui, meskipun saat ini prediksi kurang terkait dengan peramalan masa depan, namun lebih kepada pengembangan skenario individu untuk membuat dunia tampak lebih baik sehingga mereka mampu mengantisipasi berbagai kemungkinan yang terjadi (Bland, 2016).

Ada beberapa penelitian yang telah dilakukan mengenai faktor-faktor yang mempengaruhi prediksi masa depan, meskipun penelitian ini membandingkan prediksi dengan kejadian aktual (Kahneman \& Lovallo, 1991; Griffin, Dunning, \& Ross, 1990; Wilson, Wheatley, Meyers, Gilbert, \& Axsom, 2000). Di samping itu, penelitian lain menggunakan construal level theory untuk memprediksi masa depan (Liberman \& Trope, 1998; Trope, Liberman \& Wakslak, 2007; Wakslak, Nussbaum, Liberman \& Trope, 2008; Trope \& Liberman, 2010). Dari berbagai penelitian tersebut membuktikan bahwa jarak psikologis yang lebih jauh lebih menghasilkan keputusan dan kegiatan yang lebih baik (Liberman \& Trope, 1998), lebih spontan (Rim, Uleman, and Trope, 2009) dan memiliki kekuatan energi yang lebih besar dalam memprediksi masa depan (Stephan, Shidlovski, Sedikides, 2018). Dengan jarak psikologis yang jauh pun dibuktikan bahwa individu akan merasa lebih percaya diri dalam memprediksi masa depan mereka, meskipun prediksi yang dihasilkan lebih abstrak namun mampu menyiratkan tujuan mereka dengan lebih baik (Nussbaum, Liberman \& Trope, 2006).

Di sisi lain, kepercayaan diri dalam memprediksi masa depan kemungkinan juga dapat dipengaruhi oleh selfenhancement, dimana individu cenderung untuk menilai diri mereka lebih kompeten, baik hati, menarik, dan akan sukses dibanding rata-rata orang (Weinstein, 1980; Blaine \& Crocker, 1993), atau dengan kata lain, mereka lebih berharga dibanding orang lain (Alicke \& Sedikides, 2011). Kecenderungan untuk meninggikan diri sendiri dibuktikan dalam berbagai penelitian yang menunjukkan bahwa orang cenderung sangat percaya diri dalam memprediksi masa depan mereka (Alloy \& Ahrens, 1987; Dunning \& Story, 1991; Chambers \& Windschitl, 2004; Stephan, Sedikides, Heller \& Shidlovski, 2015).

Selain itu, kemungkinan prediksi kesuksesan di masa depan oleh seseorang dipengaruhi oleh adanya bias selfenhancement (Alloy \& Ahrens, 1987; Dunning \& Story, 1991) meskipun mereka menegaskan bahwa mereka kurang rentan terhadap bias tersebut daripada orang lain (Pronin, Gilovich \& Ross, 2004), sehingga hal ini dapat menyebabkan kebanyakan orang seringkali mengingat kinerja mereka lebih positif daripada yang sebenarnya (Dunning, 2007; Stephan, Sedikides, Heller, \& Shidlovski, 2015) dan menimbulkan masalah bagi mereka karena mereka merasa 
diri mereka lebih baik daripada orang lain meskipun nyatanya tidak (Preuss \& Alicke, 2009). Temuan Stephan, Sedikides, Heller \& Shidlovski (2015) juga menunjukkan bahwa prediksi masa depan dengan jarak psikologis yang jauh mampu mencerminkan "inti" diri seseorang.

"Inti" diri dapat dikatakan sebagai bagian yang otentik dari dalam diri, karena orang memiliki kebutuhan dasar untuk bertindak sesuai dengan diri sejati mereka, dengan cara yang konsisten dengan pikiran dan perasaan batin mereka (Erickson, 1995; Harter, 2002; Strohminger, Knobe, \& Newman, 2017). Perasaan otentik bermanfaat karena bersifat positif dan merupakan bentuk kesadaran akan moral pada diri (Newman, Bloom, \& Knobe, 2014), sehingga authenticity (keaslian/orisinalitas) berpotensi untuk membuat prediksi masa depan yang lebih positif. Di samping itu, authenticity juga dapat didefinisikan sebagai pengalaman yang benar-benar dimiliki secara personal oleh seseorang, baik itu pikiran, emosi, kebutuhan, keinginan, preferensi atau keyakinan dan merupakan proses yang dipahami untuk mengetahui "diri" seseorang (Harter, 2002). Dengan demikian, peneliti berasumsi bahwa selfenhancement dan authenticity mampu membuat prediksi masa depan seseorang menjadi lebih baik.

\section{Tujuan dan Manfaat Penelitian}

Penelitian ini bertujuan untuk melihat pengaruh self-enhancement dan pengalaman otentik atau tidak otentik yang dimiliki individu terhadap prediksi masa depan hidup mereka. Diharapkan penelitian ini juga mampu memperkaya literatur tentang self-enhancement atau peningkatan diri yang masih sedikit diteliti dan dieksplorasi di Indonesia.

\section{Kajian Teori}

Self-enhancement

Self-enhancement merupakan jenis motivasi yang bekerja untuk membuat orang merasa baik tentang diri mereka sendiri dan berfungsi untuk mempertahankan harga diri individu (Sedikides \& Strube, 1995). Motif ini bisa jadi sangat menonjol dalam situasi mengancam, kegagalan, atau penghinaan bagi harga diri seseorang (Beauregard \& Dunning, 1998; Krueger, 1998). Selfenhancement memiliki empat tingkatan, yaitu sebagai efek yang diamati, proses berkelanjutan, trait kepribadian, serta menjadi dasar motif bagi seseorang.

Self-enhancement juga bisa didefinisikan sebagai kecenderungan untuk mencerminkan suatu pola kesalahan yang bertahan lama (Taylor \& Brown, 1988). Hal ini didukung oleh kenyataan bahwa banyak orang yang masih memiliki kecenderungan untuk menghubungkan hasil positif dengan diri sendiri dan hasil negatif dengan situasi eksternal (Blaine \& Crocker, 1993). Selain itu, self-enhancement juga dapat bersifat universal dan dianggap sebagai "dasar" dari aktivitas psikologis (Sedikides \& Gregg, 2008). Dalam penelitian kali ini, peneliti mengacu pada definisi self-enhancement sebagai kecenderungan individu untuk menilai diri mereka lebih kompeten, baik hati, menarik, dan akan sukses dibanding rata-rata orang (Weinstein, 1980; Blaine \& Crocker, 1993).

\section{Authenticity}

Authenticity didefinisikan sebagai pengalaman yang benar-benar dimiliki secara personal oleh seseorang, baik itu pikiran, emosi, kebutuhan, keinginan, preferensi atau keyakinan dan merupakan proses yang dipahami untuk mengetahui "diri” seseorang (Harter, 2002). Authenticity juga mengacu pada perilaku yang dialami secara fenomenal oleh "diri" (Wild, 1965) atau disebabkan secara internal (Ryan, Deci, \& Grolnick, 1995). Kernis (2003) mengidentifikasi empat inti elemen dari authenticity, yaitu selfawareness, proses tanpa bias, relasional otentik dan perilaku otentik.

Orang bertindak secara otentik ketika mereka mengekspresikan diri dan memiliki keinginan untuk memilih. Asumsi ini hadir 
karena perasaan positif cenderung muncul ketika ada akses menuju sumber daya internal, seperti kemampuan untuk menyelami informasi baru (Deci \& Ryan, 1991) dan kemampuan untuk berpikir secara kreatif (Amabile, 1996). Pendeknya, adanya perasaan otentik menjadi indikator bagi seseorang yang mampu mengaktualisasikan dirinya (Rogers, 1963).

Deci \& Ryan (1995) menunjukkan bahwa authenticity muncul ketika individu mengatur diri mereka sendiri dengan cara memenuhi kebutuhan psikologis dasar mereka, seperti berkompetensi, menentukan nasib dan keterkaitan dengan orang lain. Individu juga merasa otentik kentika mereka mampu mengekspresikan konsep diri mereka (misalnya: nilai, tujuan, atau sifat) yang sesungguhnya (Kernis \& Goldman, 2006). Dalam memprediksi masa depan, individu menampilkan tujuan dan harapan diri mereka di masa yang akan datang, inilah yang menjadi dasar asumsi bahwa authenticity akan mempengaruhi prediksi masa depan seseorang menjadi lebih baik.

\section{Construal Level Theory}

Construal level theory mencakup mengenai bagaimana jarak psikologis mampu mempengaruhi perilaku dan pikiran individu. Dalam teori ini, individu diasumsikan mampu menafsirkan objek yang dekat secara psikologis mereka dengan tingkatan yang rendah, rinci dan konstektual (low-level construal). Di lain sisi, objek yang sama ditafsirkan secara berbeda menggunakan jarak psikologis yang jauh dan menghasilkan tingkatan yang lebih tinggi, abstrak, dan memiliki karakteristik yang stabil (high-level construal). Berbagai penelitian telah menunjukkan bahwa berbagai dimensi jarak psikologis (ruang, waktu, jarak sosial, dan hipotetisitas) mempengaruhi kondisi mental seseorang dalam memprediksi, mengubah sesuatu, mengevaluasi dan berperilaku (Trope, Liberman, Wakslak, 2007). Sebuah objek yang memiliki jarak psikologis ruang atau waktu, jarang mengacu pada pengalaman orang lain (kerabat, kenalan atau orang asing) namun pada pengalaman individu itu sendiri (Eyal \& Liberman, 2012).

Individu menggunakan low-level construal untuk mewakili peristiwa yang konkret dan terjadi secara dekat dan menggunakan high-level construal untuk mewakili peristiwa yang abstrak dan mampu merepresentasikan kejadian yang jauh terjadi/belum terjadi. Low-level construal juga seringkali tidak terstruktur dan konstektual, serta mencakup peristiwa yang tidak teratur dan tidak disengaja. Di sisi lain, high-level construal bersifat skematik dan mampu mengambil inti dari informasi yang tersedia (Trope, Liberman, Wakslak, 2007). Jadi, meskipun individu tidak dapat mengalami sesuatu yang belum ada atau belum terjadi, mereka dapat membuat prediksi tentang masa depan, mengingat masa lalu, membayangkan reaksi orang lain, dan berspekulasi tentang apa yang mungkin terjadi. Prediksi, ingatan, dan spekulasi semuanya adalah konstruksi mental, berbeda dari pengalaman langsung. Hal ini bekerja untuk mengatasi situasi secara langsung dan mewakili objek-objek yang jauh secara psikologis. Jarak psikologis adalah pengalaman subjektif bahwa ada sesuatu yang dekat atau jauh dari diri, di sini, dan sekarang. Jarak psikologis memiliki acuan bahwa titik awal adalah diri, di sini dan saat ini, dan berbagai cara di mana suatu objek dapat dihapus dari titik itu (waktu, ruang, jarak sosial, dan hipotetisitas) yang merupakan dimensi jarak yang berbeda-beda (Trope \& Liberman, 2010).

Temporal distance melibatkan hubungan antara waktu, situasi, atau tindakan yang dianggap berharga. Menurut Trope dan Liberman, construal level theory dapat memberikan kerangka yang dapat digunakan untuk memahami berbagai fenomena yang digambarkan oleh penelitian yang menggunakan temporal distance. Selain itu, teori ini juga menyatakan bahwa batasan waktu yang lebih singkat membuat sesuatu lebih 
berharga, namun penundaan waktu justru akan mengurangi daya tarik suatu pilihan. Di lain sisi, ketika batasan waktu yang dimiliki lebih panjang, justru suatu objek atau situasi akan lebih memiliki daya tarik yang lebih tinggi (Trope \& Liberman, 2000; Trope, 2012). Prediksi masa depan dalam penelitian ini akan diukur menggunakan construal level theory dengan jenis temporal distance.

\section{Hipotesis}

Hipotesis yang diajukan dalam penelitian ini adalah: terdapat perbedaan yang signifikan pada prediksi masa depan seseorang berdasarkan perbedaan tinggi atau rendahnya self-enhancement dan otentik atau tidaknya pengalaman seseorang

\section{METODE PENELITIAN}

\section{Identifikasi Variabel Penelitian}

Variabel independen dalam penelitian ini adalah self-enhancement dan authenticity, sedangkan variabel dependen adalah prediksi masa depan partisipan dalam penelitian ini.

\section{Desain Penelitian}

Studi ini menguji pengaruh selfenhancement dan authenticity terhadap prediksi masa depan seseorang yang diukur dengan construal level theory. Penelitian ini menggunakan metode eksperimen dengan desain random assignment 2 (selfenhancement: tinggi vs rendah) $\mathrm{x} 2$ (authenticity: otentik vs tidak otentik) dan between subjects.

\section{Partisipan Penelitian}

Sebanyak 120 orang dilibatkan dalam penelitian ini. Partisipan merupakan masyarakat umum berusia remaja sampai dewasa yang didapat melalui teknik sampling insidental. 89 orang berjenis kelamin perempuan dan 31 orang laki-laki; partisipan memiliki rentang usia 17-41 tahun ( $\mathrm{M}=24,92$ tahun, $\mathrm{SD}=4,58)$. Dalam penelitian ini, sebanyak 15,83\% berpendidikan terakhir sekolah menengah atas (SMA), 5\% orang memiliki pendidikan diploma, $71,67 \%$ bergelar sarjana, serta $7,5 \%$ orang mengenyam pendidikan magister.

\section{Instrumen Penelitian}

Self-enhancement

Self-enhancement diukur berdasarkan kemampuan partisipan dalam menilai kelemahan dan kelebihan diri mereka. Penentuan kelompok partisipan dilakukan di awal penelitian, kelompok self-enhancement tinggi diminta menuliskan kelebihan diri mereka dan kelompok self-enhancement rendah diminta menuliskan kelemahan diri mereka.

\section{Authenticity}

Peneliti mengukur authenticity partisipan dengan meminta partisipan untuk menceritakan pengalaman yang pernah mereka alami (otentik) dan pengalaman yang tidak pernah mereka alami (tidak otentik). Sebelumnya, mereka diberikan sebuah paragraf pendek yang menggambarkan skenario terkait authenticity, dengan contoh sebagai berikut:

- Pengalaman Otentik

Anto berhasil masuk ke Fakultas Teknik Arsitektur di sebuah universitas ternama. Setelah lulus dari sana, Anto berhasil meraih cita-citanya menjadi seorang arsitek terkenal di kota kelahirannya, Solo. Saat ini, ia terlibat dalam berbagai proyek besar dan memiliki gaji besar pula. Berkat usaha dan kerja kerasnya, ia pun mampu mewujudkan cita-citanya.

Paragraf di atas menjelaskan hal terbaik yang pernah dialami Anto, lalu hal apa yang pernah benar-benar terjadi dalam hidup Anda?

- Pengalaman Tidak Otentik

Rifka berharap dirinya tidak diterima di jurusan yang ia tidak suka. Ia terpaksa mendaftar ke jurusan Teknik Sipil pilihan orangtuanya karena ia hanya ingin menuruti saran mereka, namun sebenarnya Rifka lebih ingin ia 
diterima di jurusan Psikologi yang sangat ia dambakan sejak dulu.

Paragraf di atas menjelaskan hal terburuk yang dialami Silmi dalam hidupnya, lalu hal apa yang tidak anda inginkan terjadi dalam hidup Anda?

Pengalaman otentik dan tidak otentik setiap partisipan nantinya akan dikategorikan melalui teknik coding sesuai dengan tema-tema yang paling sering muncul pada tiap kelompok partisipan. Peneliti berniat untuk mengeksplorasi keunikan pengalaman setiap partisipan dengan tidak membuat skor baku dalam penelitian ini.

\section{Prediksi Masa Depan}

Dalam konteks penelitian ini, prediksi masa depan diukur melalui temporal distance atau rentang waktu psikologis. Mengacu pada construal level theory, prediksi masa depan yang didasarkan dengan rentang waktu yang jauh (future distant) memiliki hasil yang lebih baik dan dibandingkan dengan rentang waktu yang dekat (near distant) (Trope, Liberman, Wakslak, 2007). Sebab itulah, penelitian ini mengukur prediksi masa depan partisipan menggunakan temporal distance dengan jenis future distant yang berupa pertanyaan sebagai berikut: "Bayangkan peristiwa atau hal-hal apa yang akan terjadi 10 tahun kemudian. Seperti apakah diri Anda saat itu? Bagaimana Anda mendeskripsikan diri Anda di 10 tahun mendatang? Peristiwa apa yang akan terjadi dalam hidup Anda 10 tahun kemudian?".

Skor 1 diberikan untuk jawaban partisipan yang termasuk ke dalam kategori high level construal, yaitu cenderung abstrak, melihat gambaran masa depan mereka secara keseluruhan dan fokus pada inti situasi atau objek yang mereka inginkan. Selanjutnya, skor 2 diberikan untuk partisipan yang menjawab secara detail, lebih konkrit, dan memiliki gambaran yang sangat rinci namun kurang mementingkan keseluruhan situasi yang mereka inginkan di masa depan, yang termasuk dalam kategori low level construal.

\section{Prosedur Penelitian}

Prosedur penelitian ini disusun mengacu pada prosedur penelitian yang telah dilakukan oleh Stephan, Sedikides, Heller, \& Shidlovski (2015) dengan sejumlah modifikasi. Dengan demikian, prosedur yang dilakukan adalam penelitian ini adalah sebagai berikut:

a. Partisipan diminta untuk mengisi kuesioner yang disediakan dalam google form melalui tautan yang diberikan. Kuesioner ini juga meminta data demografis partisipan yang bersedia terlibat dalam penelitian.

b. Partisipan dibagi kedalam dua kelompok yaitu kelompok selfenhancement tinggi dan rendah. Pada kelompok self-enhancement tinggi, partisipan diminta untuk menuliskan kekuatan atau kelebihan diri mereka, sedangkan dalam kondisi selfenhancement rendah, partisipan diminta untuk menuliskan keburukan atau kelemahan diri mereka.

c. Setelah itu, partisipan di masingmasing kelompok diberikan satu skenario dan pertanyaan terbuka terkait authenticity. Ada empat kelompok dalam penelitian ini. Dalam kelompok self-enhancement tinggi dan otentik partisipan diminta menyatakan pengalaman terbaik yang pernah terjadi dalam hidupnya; kelompok selfenhancement tinggi dan tidak otentik diminta menyatakan pengalaman terbaik yang ia inginkan terjadi dalam hidupnya; kelompok self-enhancement rendah dan otentik diminta menyatakan pengalaman terburuk yang pernah terjadi dalam hidupnya; dan terakhir kelompok self-enhancement rendah dan tidak otentik diminta menyatakan pengalaman terburuk yang tidak ia inginkan terjadi dalam hidupnya.

d. Kemudian, seluruh partisipan dalam keempat kelompok tersebut diberikan pertanyaan mengenai bagaimana 
gambaran diri mereka di masa depan 10 tahun kemudian (future distant) untuk melihat pengaruh selfenhancement dan authenticity terhadap prediksi masa depan seseorang di masa depan.

\section{Analisis Data}

Penelitian ini menggunakan teknik statistik analisis ANOVA untuk menguji perbedaan antar kelompok serta untuk melihat perbedaan makna antar perlakuan yang diberikan (Gravetter \& Wallnau, 2014).

\section{ANALISIS DAN HASIL}

\section{Pengkodean}

Berdasar hasil penelitian yang berbentuk data kualitatif, teknik coding digunakan untuk memudahkan proses identifikasi data. Respon yang sering muncul pada jawaban partisipan di tiap-tiap kelompok dikelompokkan menjadi tematema besar untuk memudahkan proses analisis statistik. Kode atau kategori yang digunakan dalam penelitian ini adalah 1: self-enhancement tinggi; $2: \quad$ selfenhancement rendah. Selain itu, untuk menganalisis pengaruh authenticity terhadap self-prediction, peneliti mengategorikan menjadi pengalaman otentik dan tidak otentik berdasarkan tema yang muncul pada sebagian besar jawaban partisipan. Pada pengalaman otentik dibagi menjadi 7 kategori, yaitu: 1: karir; 2: akademik; 3: kemampuan diri; 4: sosial; 5: keluarga, teman, sahabat; 6:cinta; dan 7: spiritual. Pengalaman tidak otentik memiliki kategori yang sama, namun dengan satu kategori tambahan, yaitu 8: penyesalan.

Misalnya, partisipan yang menjawab seperti "Saya pernah mempunyai hubungan dengan seseorang yang berlangsung lama...namun tiba-tiba dia meminta putus dengan berbagai alasan, dan ternyata dia berselingkuh..." dalam pengalaman otentik dapat masuk kedalam kategori tema cinta. Begitu pula jawaban partisipan seperti, "Hal buruk yang benar-benar tidak saya inginkan untuk terjadi pada saya adalah ketika saya menjadi seseorang yang dibenci oleh keluarga saya, teman-teman saya, lingkungan saya, dan bahkan diri saya sendiri. Dan sayangnya saya mulai menuju ke arah sana" dalam pengalaman tidak otentik, maka dapat masuk kedalam tema keluarga, teman, sahabat.

\section{Analisis Statistik}

Penelitian ini menggunakan teknik statistik analisis ANOVA faktorial. Analisis ANOVA faktorial dilakukan sebanyak tiga kali, pertama untuk menguji pengaruh selfenhancement dan authenticity melalui empat kelompok berbeda, sedangkan analisis kedua dan ketiga dilakukan untuk melihat dan membandingkan tema pengalaman otentik dan tidak otentik mana yang memiliki pengaruh paling besar terhadap prediksi masa depan seseorang.

Tabel 1. Hasil uji deskriptif self-enhancement dan authenticity terhadap prediksi masa depan

\begin{tabular}{ccccc}
\hline Self-enhancement & Authenticity & Mean & Std Deviation & $\mathrm{N}$ \\
\hline Tinggi & Otentik & 1,67 & 0,479 & 30 \\
& Tidak Otentik & 1,50 & 0,509 & 30 \\
& Total & 1,58 & 0,497 & \\
\hline Rendah & Otentik & 1,60 & 0,498 & 30 \\
& Tidak Otentik & 1,27 & 0,450 & 30 \\
& Total & 1,43 & 0,500 & \\
\hline
\end{tabular}

Tabel 2. Hasil main effect dan efek interaksi dari self-enhancement dan authenticity terhadap prediksi masa depan

\begin{tabular}{cccccc}
\hline Sumber & $d f$ & $M S$ & $F$ & $p$ & $\begin{array}{c}\text { Effect } \\
\text { Size }\end{array}$ \\
\hline
\end{tabular}




\begin{tabular}{llllll}
\hline Self-enhancement (A) & 1 & 0,675 & 2,875 & 0,093 & 0,024 \\
Authenticity (B) & 1 & 1,875 & 7,987 & 0,006 & 0,064 \\
A x B & 1 & 0,208 & 0,887 & 0,348 & 0,008 \\
\hline
\end{tabular}

Berdasarkan hasil uji deskriptif, orang dengan self-enhancement tinggi $(M$ $=1,58 ; S D=0,49)$ memiliki hasil yang lebih baik dalam prediksi masa depan dibandingkan orang dengan selfenhancement rendah $(M=1,43 ; S D=0,50)$. Jika ditinjau dari authenticity, ternyata orang yang memiliki pengalaman otentik $(M=1,67 ; S D=0,47)$ memprediksi masa depan mereka dengan lebih baik daripada orang dengan pengalaman yang tidak otentik $(M=1,50 ; S D=0,50)$.

Hasil penelitian pun menunjukkan bahwa tidak terdapat perbedaan yang signifikan pada prediksi masa depan seseorang berdasarkan perbedaan tinggi atau rendahnya self-enhancement dan otentik atau tidaknya pengalaman seseorang $F(1 ; 116)=0,208 ; p<0,05, \eta p 2=0,008$, kemudian dari hasil analisis tersebut juga dapat diperoleh hasil bahwa tidak terdapat perbedaan signifikan pada prediksi masa depan berdasarkan self-enhancement $F(1$; 116) $=2,875 ; p<0,05, \eta \mathrm{p} 2=0,024$, dan tidak ada pula perbedaan yang signifikan pada prediksi masa depan berdasarkan authenticity $F(1 ; 116)=7,987 ; p<0,05$, $\eta \mathrm{p} 2=0,064$.

\section{Analisis Deskriptif}

Berdasarkan hasil uji deskriptif, orang-orang dengan self-enhancement tinggi dan memiliki tema pengalaman otentik mengenai keluarga, teman, sahabat memiliki prediksi masa depan lebih baik $(\mathrm{M}=2,00, \quad \mathrm{SD}=0,00) \quad$ dibanding orang dengan pengalaman otentik lain seperti tema akademik $(\mathrm{M}=1,73, \mathrm{SD}=0,46)$ dan spiritual $(M=1,67, \quad S D=0,57)$. Misalnya pada salah satu partisipan, pengalaman otentik dengan tema keluarga, teman, sahabat (Terlahir di keluarga yang penuh kasih sayang dan terus mendukung, meski saya masih jauh dari kata berhasil untuk mencapai cita-cita saya) menghasilkan prediksi masa depan yang lebih baik dan optimis (10 tahun kemudian saya akan menjadi individu yang lebih religius, lebih matang secara psikologis, lebih mandiri, sudah mencapai cita-cita, menjadi orang yang membanggakan keluarga. Saya akan menjadi manfaat bagi sesama). Prediksi masa depan ini pun lebih detail dan realistis untuk dicapai jika dibandingkan dengan pengalaman otentik dengan tema spiritual (Jumat kemarin saya memberi uang kepada yang membutuhkan, alhamdulillah setelah beberapa waktu saya dapat rejeki yg lebih besar) yang memiliki prediksi masa depan yang merujuk pada detail dan tidak mementingkan situasi masa depan secara keseluruhan (Kaya, tampan, baik, bijaksana, ramah, rajin, sabar). Kekayaan dan peningkatan kemampuan diri seperti rajin dan bijaksana tentu bisa dilakukan asal manusia berusaha, namun tampan merupakan kata sifat dan hal ini bukanlah prediksi masa depan karena bersifat relatif dan sulit diwujudkan mengingat manusia sudah terlahir dengan bentuk fisik yang berbeda-beda.

Lebih lanjut, hasil prediksi masa depan orang yang memiliki pengalaman otentik dengan tema akademik (Dulu waktu tes masuk kuliah saya pernah gagal snmptn dan gagal tes masuk politeknik kesehatan, saya tetap berusaha dan belajar sampai akhirnya saya diterima di Fakultas Psikologi di salah satu universitas terbaik di Indonesia) memiliki prediksi masa depan yang optimis, namun tidak menunjukkan situasi masa depan secara keseluruhan (10 tahun mendatang saya menjadi diri yg berhasil dalam pekerjaan dan keluarga selama selalu melakukan hal yg terbaik). Keberhasilan yang tidak dijabarkan oleh partisipan, menunjukkan bahwa ia belum memiliki gambaran masa depan yang detail tentang keberhasilan apa yang akan ia raih. Hal ini pula yang menjadi kelemahan pengalaman otentik dengan tema-tema lain selain tema keluarga, teman, dan sahabat.

Di lain sisi, orang dengan selfenhancement rendah dengan pengalaman 
otentik tema akademik justru lebih optimis dalam memprediksi masa depan mereka $(\mathrm{M}=1,83, \mathrm{SD}=0,40)$, dibandingkan dengan mereka yang memiliki pengalaman otentik dengan tema keluarga, teman dan sahabat $(\mathrm{M}=1,78, \mathrm{SD}=0,44)$. Salah satu partisipan dengan self-enhancement rendah yang memiliki pengalaman otentik dengan tema akademik (Gagal di salah satu mata kuliah) memiliki prediksi masa depan yang lebih baik ditunjukkan dengan detail-detail keberhasilan seperti apa yang akan ia wujudkan (Lulus, jadi dosen, menikah, berkarir, punya mobil sendiri, bisa bahagiain mama papa, bisa ikut kegiatan sosial sepuasnya, bisa lanjutin bisnis, bisa travelling, bisa sekolah lagi). Hal ini pun membuktikan bahwa self-enhancement yang rendah tidak mempengaruhi optimisme seseorang dalam memprediksi masa depannya.

Analisis mengenai pengalaman tidak otentik dengan tema penyesalan juga dilakukan peneliti untuk melihat tema pengalaman tidak otentik apa saja yang berpengaruh pada prediksi masa depan seseorang. Dimulai dari partisipan dengan self-enhancement tinggi, partisipan yang memiliki pengalaman tidak otentik lebih tinggi dalam memprediksi masa depan mereka pada tema akademik ( $\mathrm{M}=1,69$, $\mathrm{SD}=0,48)$ dibanding dengan tema lain seperti keluarga, teman, sahabat $(\mathrm{M}=1,64$, $\mathrm{SD}=0,50)$ dan spiritual $(\mathrm{M}=1,60, \mathrm{SD}=0,54)$.

Salah satu partisipan dengan tema akademik (Saya ingin sekali lulus S2 tepat waktu dan cumlaude dan mendapatkan pekerjaan sebagai dosen... Setelah menjadi dosen, saya berharap bisa mengembangkan diri dan mendapat beasiswa S3 ...) memiliki prediksi masa depan yang lebih baik dan penuh percaya diri (10 tahun yang akan datang saya harap saya sudah mantap berhijrah, menikah dengan suami yang penyayang dan memiliki 1-3 anak... Mungkin juga ada beberapa negara yang sudah saya kunjungi atau pulau lain yang saya kunjungi) jika dibandingkan dengan pengalaman tidak otentik tema lain seperti keluarga, teman, dan sahabat (Bisa membahagiakan orang tua) yang memiliki prediksi masa depan yang tidak jelas, yang sama sekali tidak fokus pada situasi atau objek tertentu (Bisa menjadi orang sukses di banyak bidang). Kata "sukses" dalam kalimat memiliki banyak makna dan gambaran masa depan yang tidak mendetail mencerminkan keragu-raguan partisipan dalam memprediksi masa depannya.

Lebih lanjut, partisipan dengan selfenhancement rendah pun memiliki skor yang lebih tinggi terhadap prediksi masa depan di pengalaman tidak otentik dengan tema akademik $(\mathrm{M}=1,83, \quad \mathrm{SD}=0,40)$, dibandingkan dengan pengalaman dengan tema karir $(\mathrm{M}=1,63, \mathrm{SD}=0,51)$ dan tema keluarga, sahabat dan teman $(\mathrm{M}=1,50$, $\mathrm{SD}=0,51)$. Salah satu contoh partisipan dengan self-enhancement rendah yang memiliki pengalaman tidak otentik dengan tema akademik (....saya sangat berharap agar saya tidak jatuh dan tetap selalu berada di atas, dan hal tersebutlah yang terkadang membuat saya sedikit tertekan apabila nilai yang saya dapatkan tidak cukup baik....) memiliki situasi prediksi masa depan yang jelas (Saya telah lulus S3 dan telah menikah, saya sedang bekerja sebagai dosen di suatu universitas dan memiliki beberapa proyek pembangunan serta bekerja di suatu perusahaan kontraktor ternama.....). Hal ini juga menggambarkan bahwa ia optimis melanjutkan kehidupannya seperti kebanyakan orang, yang membuktikan bahwa tinggi rendahnya self-enhancement tidak memengaruhi prediksi seseorang terhadap masa depannya.

Tabel 3. Hasil uji deskriptif self-enhancement dengan pengalaman otentik terhadap prediksi masa depan

\begin{tabular}{lllll}
\hline Self-enhancement & Tema Pengalaman Otentik & Mean & Std Deviation & $\mathrm{N}$ \\
\hline Tinggi & Karir & 1,33 & 0,577 & 3 \\
& Akademik & 1,73 & 0,467 & 11 \\
& Kemampuan diri & 1,43 & 0,535 & 7
\end{tabular}




\begin{tabular}{lllll}
\hline Self-enhancement & Tema Pengalaman Otentik & Mean & Std Deviation & $\mathrm{N}$ \\
\hline & Keluarga, teman, sahabat & 2,00 & 0,000 & 5 \\
& Spiritual & 1,67 & 0,577 & 3 \\
& Lain-lain & 2,00 & & 1 \\
& & & & 30 \\
\hline Rendah & Total & 1,80 & 0,447 & 5 \\
& Karir & 1,83 & 0,408 & 6 \\
& Akademik & 1,17 & 0,408 & 6 \\
& Kemampuan diri & 1,78 & 0,441 & 9 \\
& Keluarga, teman, sahabat & 1,33 & 0,577 & 3 \\
& Cinta & 1,00 & & 1 \\
& Lain-lain & & & 30 \\
\hline
\end{tabular}

Tabel 4. Hasil uji deskriptif self-enhancement dengan pengalaman tidak otentik terhadap prediksi masa depan

\begin{tabular}{|c|c|c|c|c|}
\hline Self-enhancement & $\begin{array}{l}\text { Tema Pengalaman } \\
\text { Tidak Otentik }\end{array}$ & Mean & Std Deviation & $\mathrm{N}$ \\
\hline \multirow{8}{*}{ Tinggi } & Karir & 1,45 & 0,522 & 11 \\
\hline & Akademik & 1,69 & 0,480 & 13 \\
\hline & Kemampuan diri & 1,56 & 0,527 & 9 \\
\hline & Sosial & 1,50 & 0,527 & 10 \\
\hline & Keluarga, teman, sahabat & 1,64 & 0,505 & 11 \\
\hline & Spiritual & 1,60 & 0,548 & 5 \\
\hline & Lain-lain & 2,00 & & 1 \\
\hline & Total & & & 30 \\
\hline \multirow[t]{8}{*}{ Rendah } & Karir & 1,63 & 0,518 & 8 \\
\hline & Akademik & 1,83 & 0,408 & 6 \\
\hline & Kemampuan diri & 1,18 & 0,405 & 11 \\
\hline & Keluarga, teman, sahabat & 1,50 & 0,512 & 22 \\
\hline & Cinta & 1,43 & 0,535 & 7 \\
\hline & Penyesalan & 1,00 & 0,000 & 3 \\
\hline & Lain-lain & 1,00 & 0,000 & 3 \\
\hline & Total & & & 30 \\
\hline
\end{tabular}

\section{DISKUSI}

Hasil penelitian ini menunjukkan bahwa orang dengan self-enhancement tinggi memiliki hasil yang lebih baik dalam prediksi masa depan dibandingkan orang dengan self-enhancement rendah. Hal ini sejalan dengan penelitian yang dilakukan Sedikides, Heller, \& Shidlovski (2015) yang menunjukkan bahwa seseorang yang memiliki atribut positif akan memprediksi masa depan dengan lebih baik dan menyenangkan, meskipun ditemukan perbedaan yang tidak signifikan antara selfenhancement tinggi dan rendah dalam penelitian ini. Dengan jarak psikologis yang jauh, individu akan lebih cenderung memiliki prediksi masa depan yang lebih positif (Wakslak, Nussbaum, Liberman \& Trope, 2008), dimana hal ini terkait dengan peningkatan optimisme, kesejahteraan hidup dan rasa bersyukur tiap orang (Gonzales, Burgess, \& Mobilio, 2001; Sheldon \& Lyubomirsky, 2006), sehingga tinggi atau rendah tingkat self-enhancement seseorang tidak berdampak pada skenario masa depan yang mereka buat.

Selain itu, hasil juga menunjukkan bahwa orang yang memiliki pengalaman otentik memprediksi masa depan mereka dengan lebih baik. Hal ini didukung oleh penelitian yang menunjukkan bahwa individu cenderung untuk memaknai diri mereka berbeda dengan orang lain dan menunjukkan konsep diri mereka dalam berbagai konteks secara konsisten, sehingga memunculkan adanya perasaan otentik yang kuat dalam diri mereka (Cross, Gore, \& Morris, 2003). Tentunya faktor ini berpengaruh besar pada prediksi masa 
depan mereka yang lebih positif daripada orang dengan pengalaman yang tidak otentik, meskipun beda pengaruh tersebut tidak signifikan.

Lebih lanjut, tidak adanya perbedaan yang signifikan pada prediksi masa depan seseorang berdasarkan perbedaan tinggi atau rendahnya selfenhancement dan otentik atau tidaknya pengalaman seseorang juga dapat dipengaruhi oleh minimnya jumlah partisipan di tiap-tiap kelompok dan juga tidak adanya penentuan skor yang jelas, sehingga data menjadi tidak normal dan sulit untuk dibuktikan melalui analisis secara statistik.

Ketika membayangkan masa depan, kebanyakan orang akan fokus kepada skenario positif yang mereka buat (NewbyClark \& Ross, 2003), sebagai manifestasi dari peningkatan diri seseorang di masa depan (Heller, Stephan, Kifer, \& Sedikides, 2011). Hal ini mendukung hasil penelitian ini yang menunjukkan bahwa sebagian besar partisipan mengemukakan gambaran masa depan mereka secara optimis, yang juga menggambarkan keinginan dan tujuan yang mereka harapkan dapat terealisasi di masa depan (Markus \& Wurf, 1987).

Authenticity terkait erat dengan identitas diri seseorang; identitas yang merupakan dasar dari konsep diri dan nilai individu (Erickson, 1995). Berbagai tematema pengalaman otentik yang dijabarkan oleh partisipan bisa jadi merupakan "diri" mereka yang sesungguhnya. Hal ini didukung oleh George (1998) yang menyatakan bahwa orang-orang memiliki 'sense of authenticity' yang merujuk pada perasaan bahwa kehidupan seseorang baik publik maupun pribadi mencerminkan diri sejati mereka.

Dari hasil penelitian yang dilakukan, orang dengan self-enhancement tinggi dan memiliki tema pengalaman otentik mengenai keluarga, teman, sahabat memiliki prediksi masa depan lebih baik. Sejalan dengan yang dikatakan Adams \& Marshall (1996) bahwa sosialisasi dalam lingkungan keluarga dan pengaruh orangtua memiliki kemampuan untuk membedakan individu dengan orang lain, sehingga mereka akan memunculkan "diri" yang sejati dan berperilaku secara otentik. Hal ini tentunya akan mendukung gambaran diri masa depan mereka yang lebih sukses dan lebih baik, jika dibandingkan dengan partisipan yang memiliki self-enhancement tinggi dengan pengalaman tidak otentik.

Di sisi lain, orang dengan selfenhancement rendah dengan pengalaman otentik dan tidak otentik lebih tinggi samasama lebih tinggi pada tema akademik. Hal ini kemungkinan dapat dipengaruhi oleh peningkatan rasa percaya diri yang didukung oleh keberhasilan dalam bidang pendidikan. Di Indonesia, memiliki gelar sarjana atau master merupakan suatu kebanggaan, sehingga ada kemungkinan besar gambaran masa depan yang lebih baik pada partisipan dipengaruhi oleh faktor tersebut.

Dengan demikian, penelitian ini masih memiliki berbagai keterbatasan, diantaranya adalah tidak digunakannya alat ukur yang terstruktur untuk mengukur variabel penelitian serta adanya bias kultur yang tidak dikontrol dalam penelitian ini.

\section{SIMPULAN}

Orang dengan self-enhancement tinggi memiliki hasil yang lebih baik dalam prediksi masa depan dibandingkan orang dengan self-enhancement rendah. Dengan jarak psikologis yang jauh, individu akan lebih cenderung memiliki prediksi masa depan yang lebih positif, sehingga tinggi atau rendah tingkat self-enhancement seseorang tidak berdampak pada skenario masa depan yang mereka buat.

Selain itu, terlepas dari pengalaman otentik atau tidak otentik, hasil penelitian ini yang menunjukkan bahwa sebagian besar partisipan mengemukakan gambaran masa depan mereka secara optimis, yang juga menggambarkan keinginan dan tujuan yang mereka harapkan dapat terealisasi di masa depan yang muncul dalam berbagai tema-tema besar dalam penelitian ini. 


\section{SARAN}

Minimnya jumlah partisipan sedikit banyak berpengaruh pada hasil penelitian. Selain itu, penggunaan pertanyaan terbuka pun ternyata kurang cocok diaplikasikan pada budaya Indonesia, terbukti bahwa prediksi masa depan partisipan yang diukur menghasilkan jawaban yang cenderung optimis terhadap masa depan mereka. Berdasarkan kekurangan pada penelitian ini, pada penelitian selanjutnya diharapkan untuk menggunakan instrumen penelitian yang lebih terstruktur dan jumlah partisipan yang lebih banyak sehingga hasil penelitian mampu dianalisis dengan lebih optimal.

Selain itu bagi masyarakat umum, diharapkan untuk berlatih untuk memprediksi masa depan sesuai dengan kemampuan diri masing-masing. Kecenderungan masyarakat Indonesia yang senang berandai-andai harus diiringi dengan usaha yang sepadan untuk meraih masa depan yang lebih baik.

\section{DAFTAR PUSTAKA}

Adams, G.R., \& Marshall, S.K. (1996). A developmental social psychology of identity: Understanding the person-in context. Journal of adolescence, 19(5), 329-442.

Alicke, M.D., \& Sedikides, C. (2011). Handbook of self-enhancement and selfprotection. Guilford Press.

Alloy, L.B., \& Ahrens, A. H. (1987). Depression and pessimism for the future: biased use of statistically relevant information in predictions for self versus others. Journal of personality and social psychology, 52(2), 366.

Blaine, B., \& Crocker, J. (1993). Self-esteem and self-serving biases in reactions to positive and negative events: An integrative review. Dalam Self-esteem (hal. 55-85). Springer, Boston, MA.

Bland, J. (2016, Januari 7). Accuracy and ambition - why do we try to predict the future? Diunduh dari

https://www.nesta.org.uk/blog/accuracyand-ambition-why-do-we-try-to-predictthe-future/

Beauregard, K.S., \& Dunning, D. (1998). Turning up the contrast: selfenhancement motives prompt egocentric contrast effects in social judgments. Journal of personality and social psychology, 74(3), 606.

Chambers, J. R., \& Windschitl, P. D. (2004). Biases in social comparative judgments: the role of nonmotivated factors in above-average and comparativeoptimism effects. Psychological bulletin, 130(5), 813.

Cross, S. E., Gore, J. S., \& Morris, M. L. (2003). The relational-interdependent self-construal, self-concept consistency, and well-being. Journal of personality and social psychology, 85(5), 933.

Deci, E.L., \& Ryan, R. M. (1991). A motivational approach to self: Integration in personality. Tn R. Dienstbier (Ed.), Nebraska Symposium on Motivation: Perspectives on motivation (Vol. 38, hal. 237-288). Lincoln: University of Nebraska Press.

Dunning, D. (2007). Self-image motives and consumer behavior: how sacrosanct selfbeliefs sway preferences in the marketplace. Journal of Consumer Psychology, 17(4), 237-249.

Dunning, D., \& Story, A. L. (1991). Depression, realism, and the overconfidence effect: Are the sadder wiser when predicting future actions and events?. Journal of personality and social psychology, 61(4), 521.

Erickson, R. J. (1995). The importance of authenticity for self and society. Symbolic interaction, 18(2), 121144.

Eyal, T., \& Liberman, N. (2012). Morality and psychological distance: A construal level theory perspective. The social psychology of morality: Exploring the causes of good and evil, 185-202.

George, L. K. (1998). Self and identity in later life: Protecting and enhancing the self. Journal of Aging and Identity, 3(3), 133-152.

Gonzales, M. H., Burgess, D. J., \& Mobilio, L. J. (2001). The allure of bad plans: Implications of plan quality for progress 
toward possible selves and postplanning energization. Basic and applied social psychology, 23(2), 87-108.

Gravetter, F., \& Wallnau, L. (2014). Introduction to the t statistic. Essentials of Statistics for the Behavioral Sciences, 8, 252.

Griffin, D. W., Dunning, D., \& Ross, L. (1990). The role of construal processes in overconfident predictions about the self and others. Journal of personality and social psychology, 59(6), 1128.

Harter, S. (2002). Authenticity. Dalam C. R. Snyder \& S. J. Lopez. Handbook of positive psychology (hal. 382-394). New York, NY, US: Oxford University Press

Heller, D., Stephan, E., Kifer, Y., \& Sedikides, C. (2011). What will I be? The role of temporal perspective in predictions of affect, traits, and self-narratives. Journal of Experimental Social Psychology, 47(3), 610-615.

Kahneman, D., \& Lovallo, D. (1993). Timid choices and bold forecasts: A cognitive perspective on risk taking. Management science, 39(1), 17-31.

Kernis, M. H. (2003). Toward a conceptualization of optimal selfesteem. Psychological inquiry, 14(1), 126.

Kernis, M. H., \& Goldman, B. M. (2006). A multicomponent conceptualization of authenticity: Theory and research. Advances in experimental social psychology, 38, 283-357.

Krueger, J. (1998). Enhancement Bias in Descriptions of Self and Others. Personality and Social Psychology Bulletin, 24 (5), 505-516.

Liberman, N., \& Trope, Y. (1998). The role of feasibility and desirability considerations in near and distant future decisions: A test of temporal construal theory. Journal of personality and social psychology, 75(1), 5 .

Liberman, N., Trope, Y., \& Rim, S. (2011). Prediction: A construal-level theory perspective. Predictions in the brain: Using our past to generate a future, 144158.

Markus, H., \& Wurf, E. (1987). The dynamic self-concept: A social psychological perspective. Annual review of psychology, 38(1), 299-337.
Newby-Clark, I. R., \& Ross, M. (2003). Conceiving the past and future. Personality and Social Psychology Bulletin, 29(7), 807-818.

Newman, G. E., Bloom, P., \& Knobe, J. (2014). Value judgments and the true self. Personality and Social Psychology Bulletin, 40(2), 203-216.

Nussbaum, S., Liberman, N., \& Trope, Y. (2006). Predicting the near and distant future. Journal of Experimental Psychology:General, 135(2), 152.

Preuss, G. S., \& Alicke, M. D. (2009). Everybody loves me: Self-evaluations and metaperceptions of dating popularity. Personality and Social Psychology Bulletin, 35(7), 937-950.

Pronin, E., Gilovich, T., \& Ross, L. (2004). Objectivity in the eye of the beholder: divergent perceptions of bias in self versus others. Psychological review, 111(3), 781.

Rim, S., Uleman, J. S., \& Trope, Y. (2009). Spontaneous trait inference and construal level theory: Psychological distance increases nonconscious trait thinking. Journal of experimental social psychology, 45(5), 1088-1097.

Rogers, C. R. (1963). Toward a science of the person. Journal of Humanistic Psychology, 3(2), 72-92.

Sedikides, C., Strube, M. J. (1995). The Multiply Motivated Self. Personality and Social Psychology Bulletin, 21 (12), 1330-1335.

Sedikides, C., \& Gregg, A. P. (2008). Selfenhancement: Food for thought. Perspectives on Psychological Science, 3(2), 102-116.

Sheldon, K. M., \& Lyubomirsky, S. (2006). How to increase and sustain positive emotion: The effects of expressing gratitude and visualizing best possible selves. The journal of positive psychology, 1(2), 73-82.

Stephan, E., Sedikides, C., Heller, D., and Shidlovski, D. (2015). My Fair Future Self: The Role of Temporal Distance and Self-Enhancement in Prediction. Social Cognition, 33(2), 149-168.

Strohminger, N., Knobe, J., \& Newman, G. (2017). The true self: A psychological concept distinct from the self. Perspectives on Psychological Science, 12(4), 551-560. 
Taylor, S. E., \& Brown, J. D. (1988). Illusion and well-being: a social psychological perspective on mental health. Psychological bulletin,103(2), 193.

Trope, Y., \& Liberman, N. (2000). Temporal construal and time-dependent changes in preference. Journal of personality and social psychology, 79(6), 876.

Trope, Y., \& Liberman, N. (2010). Construallevel theory of psychological distance. Psychological review, 117(2), 440.

Trope, Y., Liberman, N., \& Wakslak, C. (2007). Construal levels and psychological distance: Effects on representation, prediction, evaluation, and behavior. Journal of consumer psychology, 17(2), 83-95.

Trope, Y. (2012). Construal Level Theory. In P. K. Van Lange, Handbook of Theories of Social Psychology (hal. 118-134). Washington DC: Sage Publications Ltd.
Wakslak, C. J., Nussbaum, S., Liberman, N., \& Trope, Y. (2008). Representations of the self in the near and distant future. Journal of personality and social psychology, 95(4), 757.

Weinstein, N. D. (1980). Unrealistic optimism about future life events. Journal of personality and social psychology, 39(5), 806.

Wild, J. (1965). Authentic existence: A new approach to "value theory." In J. M. Edie (Ed.). An invitation to phenomenology: Studies in the philosophy of experience (hal. 59-78). Chicago: Quadrangle Books.

Wilson, T. D., Wheatley, T., Meyers, J. M., Gilbert, D. T., \& Axsom, D. (2000). Focalism: A source of durability bias in affective forecasting. Journal of personality and social psychology, 78(5), 821. 